\title{
Relationship between Emotional Intelligence and Physical Fitness with Football Referee Performance
}

\author{
Yudi Nurcahya*, Dadan Mulyana, Sagitarius Sagitarius \\ Faculty of Sport Education and Health \\ Universitas Pendidikan Indonesia \\ Bandung, Indonesia \\ *udinurcahya@upi.edu
}

\begin{abstract}
The purpose of this study is to analyze the relationship between emotional intelligence and physical fitness with the performance of football referees. This study uses a quantitative approach with descriptive research methods. Data analysis techniques used were Pearson correlation and linear regression. This research was conducted at the Association of PSSI Bandung by taking the research subjects, 11 referees using purposive sampling. The research instrument used was Emotional Intelligence Test through emotional intelligence questionnaire, Physical Fitness Test through FIFA Fitness Test for Referee, and Referee Performance Test using FIFA Referee Assessment. The results showed that: There was a significant relationship between emotional intelligence and referee performance, There was a significant relationship between physical fitness and referee performance. The implications of this study are: Clarifying the factors related to the performance of the football referee, being a consideration in choosing a qualified football referee.
\end{abstract} fitness

Keywords—soccer referee; emotional intelligence; physical

\section{INTRODUCTION}

One component that gives an important role in the smoothness of a soccer match is the referee. Football referee is a leader in a football match who is in charge and responsible for the course of a match. The referee is in charge of leading the way in football matches in accordance with the rules of the football game with the help of two assistant referees and one fourth official [1]. The referee collaborates with two assistant referees who have full authority to control and regulate the behavior of players and coaches [2]. The good and bad of a football match is greatly influenced by the performance of the referee. The role of the referee is very important in football, especially in professional football, wrong decisions may have profound implications for the outcome of the match [3]. For this reason referees are led to have a high level of physical fitness and a good understanding of the rules of football. Knowledge that is better than the soccer committee can clearly benefit the game [3].

The phenomenon that occurred in Indonesia many teams were not satisfied with the performance of the referee who led the match. This is due to some mistakes made by a referee.
Factors that influence the performance of referees are very complex consisting of physical factors and psychological factors (mental). A person's performance is influenced by practice and work experience, education, attitudes, personality, organization, leaders, physical condition, abilities and motivation [4]. The non-optimal performance of the referee in the field can occur due to declining physical conditions. Referee is guided to have high physical fitness to be able to support his performance when leading the match. In a competitive match, an elite referee can reach a distance of 9-13 $\mathrm{km}$, the distance is the same as that achieved by football players especially midfielders [5]. In one match the referee can take 10-14 km [6]. This shows that the referee is told to have excellent physical fitness to be able to reach that distance. Decreased physical conditions can cause a referee to experience fatigue quickly. Fatigue will continue to increase while work performance will continue to decline [7]. This indicates that the fatigue experienced will disrupt the performance of the referee, so it is very possible for a referee to make a mistake in decision making.

A referee often experiences pressure from the field, whether it's done by a player, official, or spectator. Emotional management of a referee is very necessary in this case. Emotional Quotient (EQ) is the ability to motivate yourself, control feelings and impulses to keep stress from turning off the ability to think, empathize and apply emotional intelligence effectively [8]. The cognitive perceptual aspect turned out to have an effect on accuracy in decision making in football games [9]. For this reason a referee must have emotional intelligence to be able to overcome the pressures that arise. People who have emotional intelligence will be able to face challenges and make a human being full of responsibility, productive and optimistic in facing and solving problems, where these things are needed in the work environment [10]. With the emotional intelligence of a referee, he will feel confident with the abilities he has. A person who lacks confidence tends to feel anxious, lacks focus on the strength he has, and the concentration on the task at hand is easily disturbed [11]. There is a positive relationship between emotional intelligence and athletic success in groups and individual sports [12]. 
Based on several phenomena of existing problems, there is still a lack of research on emotional intelligence in football referees in Indonesia, so researchers need to find out whether emotional intelligence and physical fitness possessed by a football referee has a relationship with the performance of the football referee.

\section{METHOD}

This research uses descriptive method, in order to analyze the relationship of emotional intelligence, and physical fitness with the performance of football referees. The population in this study were football referees members of the Bandung PSSI Association which numbered 96 referees. The sample in this study amounted to 11 people taken by purposive sampling technique.

The instrument in this study uses emotional intelligence tests using questionnaires as research instruments. Formulation of questionnaire questions is adjusted to what will be examined. And to measure physical fitness, in this study using the FIFA Fitness Test for Referee, consisting of two test components, namely the Sprint test and Interval test. Determination of a measuring instrument to assess the performance of the referee, the author uses from the assessment of the referee that is used or applies in PSSI. This form is an official form issued by FIFA and is often used by PSSI to measure the performance of football referees. Data analysis techniques used were Pearson correlation and linear regression.

\section{RESULT AND DISCUSSION}

Based on the processing and analysis of data with descriptive statistical approach shows that:

- In the study there is a relationship between emotional intelligence and the performance of the referee with a correlation coefficient of 0.814 which indicates that there is a very strong relationship.

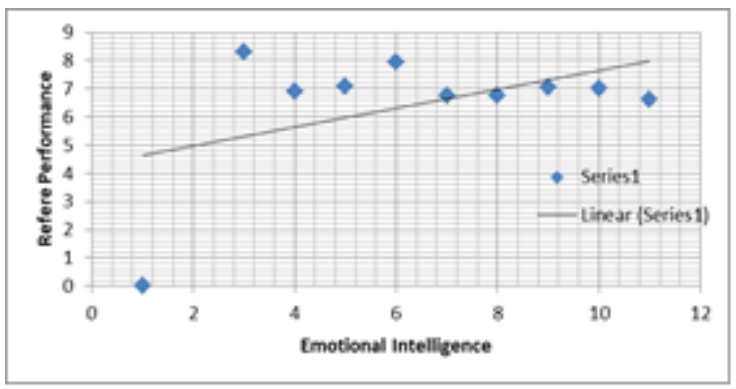

Fig. 1. EQ correlation test with referee performance.

While the contribution of emotional intelligence to the referee's performance was $66.3 \%$. In this study it was found that emotional intelligence provides the greatest contribution to referee performance compared to physical fitness. This proves that emotional intelligence is one of the very important internal factors that must be possessed by a football referee to support its performance in the field. For this reason, a program is needed to increase the emotional intelligence of referees to support their performance when leading a soccer match.
- In this study there was a significant relationship between physical fitness and referee performance with correlation coefficient of 0.637 .

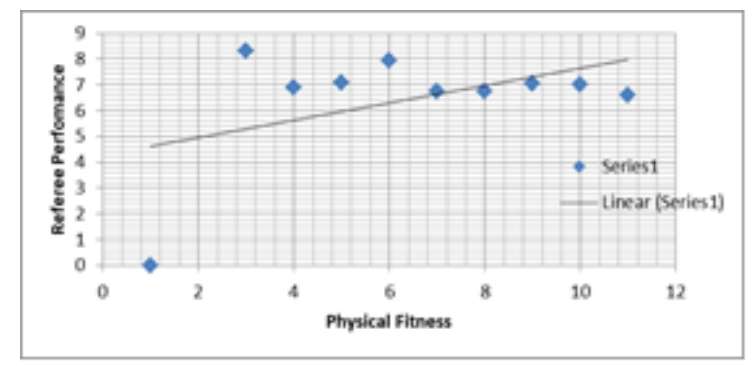

Fig. 2. Test of correlation of physical fitness with referee performance.

This indicates that there is a very strong relationship between physical fitness and referee performance. While the contribution of physical fitness to the referee's performance was $47.7 \%$. In this study it was found that physical fitness factors contributed less to the performance of soccer referees when compared to emotional intelligence. This shows that psychological factors contribute more when compared to physical factors.

- Physical fitness, and emotional intelligence are very instrumental in improving the performance of the referee when leading a match. After processing and analyzing data, it was found that there was a significant relationship between emotional intelligence and physical fitness with football referee performance, with a correlation between intellectual intelligence, emotional intelligence, and physical fitness with the performance of football referees of 0.872 . This value shows that there is a very strong relationship between intellectual intelligence, emotional intelligence, and physical fitness with the performance of football referees.

In this study it was found that the coefficient of determination of $\mathrm{R}$ square of 0.620 implies that the contribution of emotional intelligence, and physical fitness to the performance of the football referee was $62.0 \%$, while the remaining $38.0 \%$ was influenced by other factors. These results indicate that emotional intelligence, and physical fitness have a very strong relationship and have contributed to the performance of the football referee. Another factor that influences the performance of a soccer referee other than emotional intelligence, and physical fitness which is an internal factor of a referee is motivation, understanding the rules of the game, and the experience of a referee. While external factors that influence the performance of the football referee are facilities, competition, and spectators at the stadium.

\section{CONCLUSION}

Based on the results of the study, the following conclusions can be drawn:

- There is a significant relationship between emotional intelligence and the performance of football referees. Emotional intelligence has a relationship with 
performance is football, because a person's ability to manage effective intelligence from the core components of emotional intelligence [13]. In sports, negative transitions such as transitions, corrections, and recovery can optimize optimal performance. Thus, energy control, such as emotional intelligence, supporting intelligence and managing emotions can maximize performance [14].

- There is a significant relationship between physical fitness and the performance of football referees. Physical fitness certainly has a relationship with the performance of football referees. A football match in both the league and league will take place strictly, which is a factor supporting the success of the match. Just like soccer players, referees also need good physical fitness to support their performance.

- The results of this study are expected to be a reference for various parties related to the development of improving the quality of football referees judging from aspects of intellectual intelligence, emotional intelligence, and physical fitness. In connection with the research that has been done, the authors propose the following recommendations: The referee committee of football can use the results of research and literature review to develop a model or program of football referee training that is structured and based on facts, so that the process of coaching and training of soccer referees becomes more effective.

- The results of this study can be a reference as well as a starting point for further study of aspects of psychology in addition to intellectual intelligence and emotional intelligence which contribute to the performance of football referees, such as spatial intelligence and spiritual intelligence. In addition, aspects of physical fitness are expected to be further investigated in their contribution to the performance of football referees, especially from the physical fitness component that was not examined in this study.

\section{REFERENCES}

[1] FIFA, Law of The Game, 2014.

[2] D. Castillo, J. Yanci, J. A. Casajús, and J. Cámara, "Physical fitness and physiological characteristics of soccer referees," Science \& Sports, vol. 31(1), pp. 27-35, 2016.

[3] C. Castagna, G. Abt, and S. D'Ottavio, "Physiological aspects of soccer refereeing performance and training," Sports medicine, pp. 37(7), vol. 625-646, 2007.

[4] A.P. Mangkunegara, Manajemen Sumber Daya Manusia. Bandung: PT. Remaja Rosda Karya, 2000

[5] C. Castagna, G. Abt, and S. D'Ottavio, "Relation between fitness tests and match performance in elite Italian soccer referees," Journal of strength and conditioning research, vol. 16(2), pp. 231-235, 2002.

[6] FIFA, FIFA Fitness RAP. 2010

[7] S. Giriwijoyo and D.Z. Sidik, Ilmu Faal Olahraga (Fungsi Tubuh Manusia Pada Olahraga Untuk Kesehatan dan untuk Prestasi). Bandung: FPOK UPI, 2010

[8] D. Goleman, and A.T.K. Widodo, Kecerdasan emosi untuk mencapai puncak prestasi. Jakarta: Gramedia Pustaka Utama, 1999.

[9] F. Casanova, J. Oliveira, M. Williams, and J. Garganta, Expertise and perceptual-cognitive performance in soccer: a review," Revista Portuguesa de Ciências do Desporto, vol. 9(1), pp. 115-122, 2009.

[10] P. Patton, Kecerdasan Emosional di Tempat Kerja, Alih Bahasa : Zaini Dahlan. Jakarta: Pustaka Delaprata, 1998.

[11] R. Weinberg and D. Gould, Foundation of sport and exercise psychology. Champaign, IL: Human Kinetic, 1995.

[12] R. Sohrabi, P.A. Garajeh, and A. Mohammadi, "Comparative study of emotional intelligence of athlete and non-athlete female students of Tabriz islamic Azad university," Procedia-Social and Behavioral Sciences, vol. 30, pp. 1846-1848, 2011.

[13] P. Salovey and J.D. Mayer, "Emotional intelligence," Imagination, cognition and personality, vol. 9(3), pp. 185-211, 1990

[14] P.E. Salovey and D.J. Sluyter, Emotional development and emotional intelligence: Educational implications. Basic Books, 1997. 